\title{
CONFORMATIONAL FLEXIBILITY IN ENKEPHALINS: SOLVENT DEPENDENT TRANSITIONS IN PEPTIDES WITH GLY - GLY SEGMENTS DETECTED BY CIRCULAR DICHROISM
}

\author{
T. S. SUDHA and P. BALARAM* \\ Molecular Biophysics Unit and Solid State and Structural Chemistry Unit, Indian Institut of Science, Bangalore-560 012, India
}

\section{Introduction}

The widespread interest in developing structureactivity correlations for opioid peptides [1-3] has led to a large number of investigations on the preferred solution conformations of enkephalins [4-11]. The results of these studies have led to proposals ranging from $\beta$-turn conformations. With Gly ${ }^{2}-$ Gly $^{3}$ [14] or $\mathrm{Gly}^{3}-\mathrm{Phe}^{4}[\mathbf{4}-10]$ as the corner residues. Evidence for the lack of preferred conformations in solutions, resulting from dynamic averaging between an ensemhle of structures, has also been presented [11]. While a consensus has yet to be reached on the solution conformations of enkephalins, there is general agreement that receptor interactions presumably involve a folded, defined conformation of the pentapeptide [12-14]. The recognition of multiple receptor sites for opioid ligands [15-17], has provided a further impetus for studies of conformational flexibility in enkephalins, with the possibility that interaction at $\mu$ and $\delta$ sites may be mediated through different conformations of the peptides [18]. Here, we describe an unusual solvent-dependent conformational transition, in the protected fragment Boc-GlyGly-Phe-Met- $-\mathrm{NH}_{2}$ and $\mathrm{Met}^{5}$-enkephalinamide which is abolished on restricting conformational freedom by substitution of Gly by a-aminoisobutyryl (Aib) residues $[19,20]$.

\footnotetext{
Abbreviations: Aib, a-aminoisobutyryl; DCC, $N, N^{\prime}$-dicyclohexylcarbodiimide; TLC, thin-layer chromatography; Boc, t-butyloxycarbonyl; TFE, trifluoroethanol

* 1 o whom correspondence should be addressed
}

\section{Experimental}

All peptides were synthesized by solution phase procedures using DCC or DCC-1-hydroxybenzotriazole mediated couplings. Peptides were characterized by $270 \mathrm{MHz}{ }^{1} \mathrm{H}$ NMR and checked for homogeneity by TLC on silica gel. CD spectra were recorded on a JASCO 5-20 spectropolarimeter using cells of $1 \mathrm{~mm}$ pathlength. Molar ellipticities $[\theta]_{\mathrm{M}}$ were calculated using the formula:

$$
[\theta]_{\mathrm{M}}=\left(\theta_{\text {obs }} \times M_{\mathrm{r}}\right) / 10 C \cdot l \mathrm{deg} \cdot \mathrm{cm}^{2} \cdot \mathrm{dmol}^{-1}
$$

where

$$
\begin{aligned}
& \theta_{\text {obs }}=\text { observed reading in degrees; } \\
& C \quad=\text { concentration in } \mathrm{g} / \mathrm{ml} ; \\
& l \quad=\text { pathlength in } \mathrm{cm} .
\end{aligned}
$$

${ }^{1} \mathrm{H}$ NMR studies were carried out on a Bruker WH-270 FT-NMR spectrometer at the Bangalore NMR Facility. Amide NH resonances of Phc and Met were unambiguously identified by spin decoupling experiments, which established the connectivities between $\mathrm{C}^{\beta} \mathrm{H}_{2}, \mathrm{C}^{\alpha} \mathrm{H}$ and $\mathrm{NH}$ protons. Variable temperature measurements were carried out in $\left(\mathrm{CD}_{3}\right)_{2} \mathrm{SO}$ over $20-80^{\circ} \mathrm{C}$, at $10 \mathrm{mg}$ peptide $/ \mathrm{ml}$.

\section{Results and discussion}

Fig. 1 shows the CD spectrum of Boc-Gly-GlyPhe-Met- $\mathrm{NH}_{2}$ (I) in methanol, trifluoroethanol (TFE) and a $\mathbf{l}: 1(\mathrm{v} / \mathrm{v})$ mixture of these solvents. In $\mathrm{MeOH}$, a weak negative band at $235 \mathrm{~nm}$ and a strong 


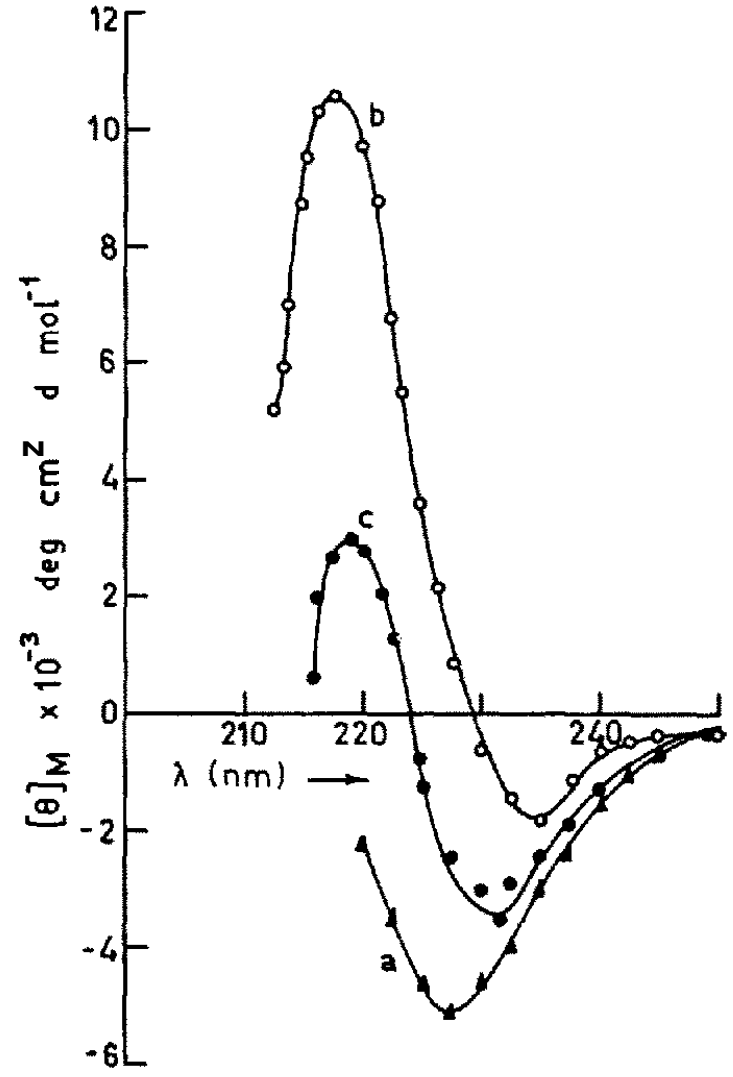

Fig.1. CD spectra of Boc-Gly-Gly - Phe-Met-NH 1 (1.96 mM) in: (a) TFE; (b) MeOH; (c) TFE-MeOH, 1:1 (v/v).

positive band at $218 \mathrm{~nm}$ is observed, whereas in TFE there is a dramatic change, with only a negative band at $228 \mathrm{~nm}$. This suggests that the peptide undergoes a large conformational change on going from $\mathrm{MeOH}$ to TFE. Interestingly, the spectrum in a 1:1 solvent mixture (fig.1 c), exhibits CD bands characteristic of both solvents, suggesting that different conforma* tional states may be populated. A similar solvent dependent reversal of the signs of the CD bands is also observed in $\mathrm{Met}^{5}$-enkephalinamide (Tyr-GlyGly-Phe-Met-NH ${ }_{2}$ ) and Boc-Tyr-Gly-Gly-PheLeu. $\mathrm{NH}_{2}$ (fig.2). Aib residues, in which both $\mathrm{C}^{\alpha}$ hydrogens of Gly are replaced by methyl groups, can be used to restrict the conformational flexibility of small acyclic peptides [21]. Fig.3 shows the CD spectra of $\mathbf{3}$ tetrapeptides, in which the Gly residues are separately and simultaneously replaced by Aib residues. Both Boc-Aib-Gly-Phe-Met-NH $\mathrm{NH}_{2}(2)$ and Boc$\mathrm{Aib}-\mathrm{Aib}-\mathrm{Phe}-\mathrm{Met} \cdot \mathrm{NH}_{2}$ (3) show positive $\mathrm{CD}$ bands

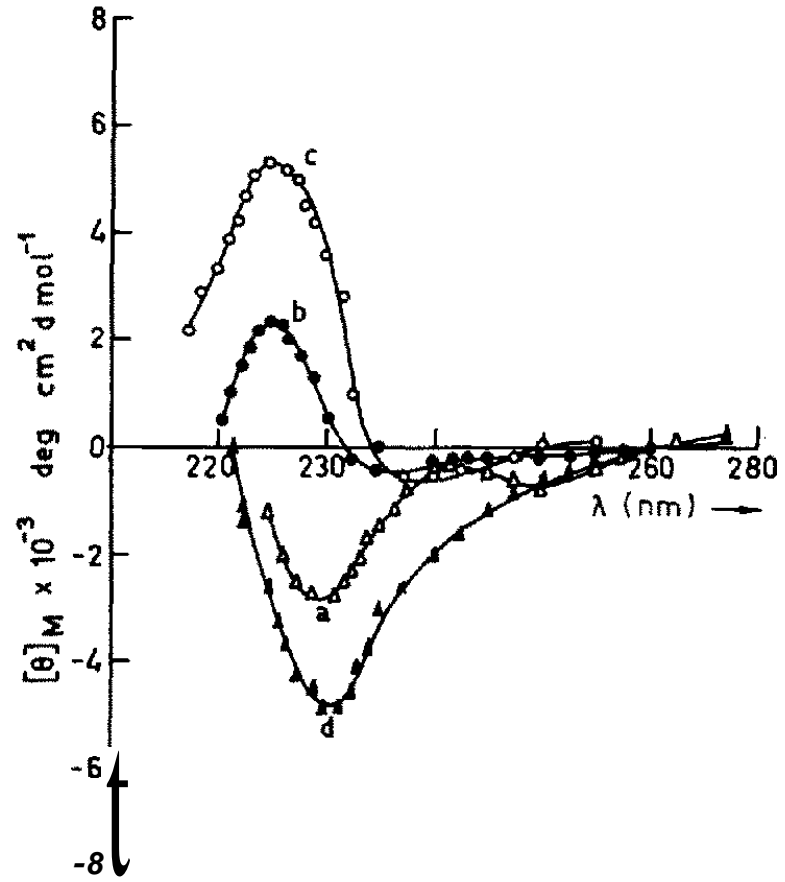

Fig.2. CD spectra of Tyz-Gly-Gly-Phe-Met-NH $(1.74 \mathrm{mM})$ in: (a) MeOH and (b) TFE; Boc-Tyr-Gly-Gly-Phe-Leu$\mathrm{NH}_{2}(1.53 \mathrm{mM})$ in (c) MeOH and (d) TFE.

at $218 \mathbf{n m}$ in $\mathrm{MeOH}$ as observed for $\mathbf{1}$. However, in the case of Boc-Gly-Aib-Phe-Met- $\mathrm{NH}_{2}$ (4) a negative band at $216 \mathrm{~nm}$ is observed. In all the Aib-substituted peptides there is no change in the sign of the $\mathrm{CD}$ band on going from $\mathrm{MeOH}$ to TFE. Small shifts in band position and changes in intensity are observed. The relevant $C D$ parameters for these peptides are summarized in table 1 . The CD spectra were concentration-dependent over 1-2 $\mathrm{mM}$ in TFE.

The above results establish that Boc-Gly-GlyPhe-Met- $\mathrm{NH}_{2}$ (1), Met ${ }^{5}$ enikephalinamide and BocTyr-Gly-Gly-Phe-Leu-NH $\mathrm{NH}_{2}$ show pronounced solvent-dependent conformational equilibria. Substitution of Gly by Aib abolishes this degree of flexibility. Earlier studies of Aib peptides, have clearly established the propensity of $\mathrm{Aib}-\mathrm{X}$ and $\mathrm{X}-\mathrm{Aib}$ sequences to adopt $\beta$-turn conformations, stabilized by an intramolecular $4 \rightarrow 1$ hydrogen bond [21-25]. ${ }^{1}$ H NMR studies of the tetrapeptides have been carried out to delineate the intramolecularly hydrogenbonded NH groups. Temperature coefficients $(\mathrm{d} \delta / \mathrm{d} T)$ of the Phe and Met NH-groups, determined in $\left(\mathrm{CD}_{3}\right)_{2} \mathrm{SO}$, are summarized in table 1. In 2 the Phe 


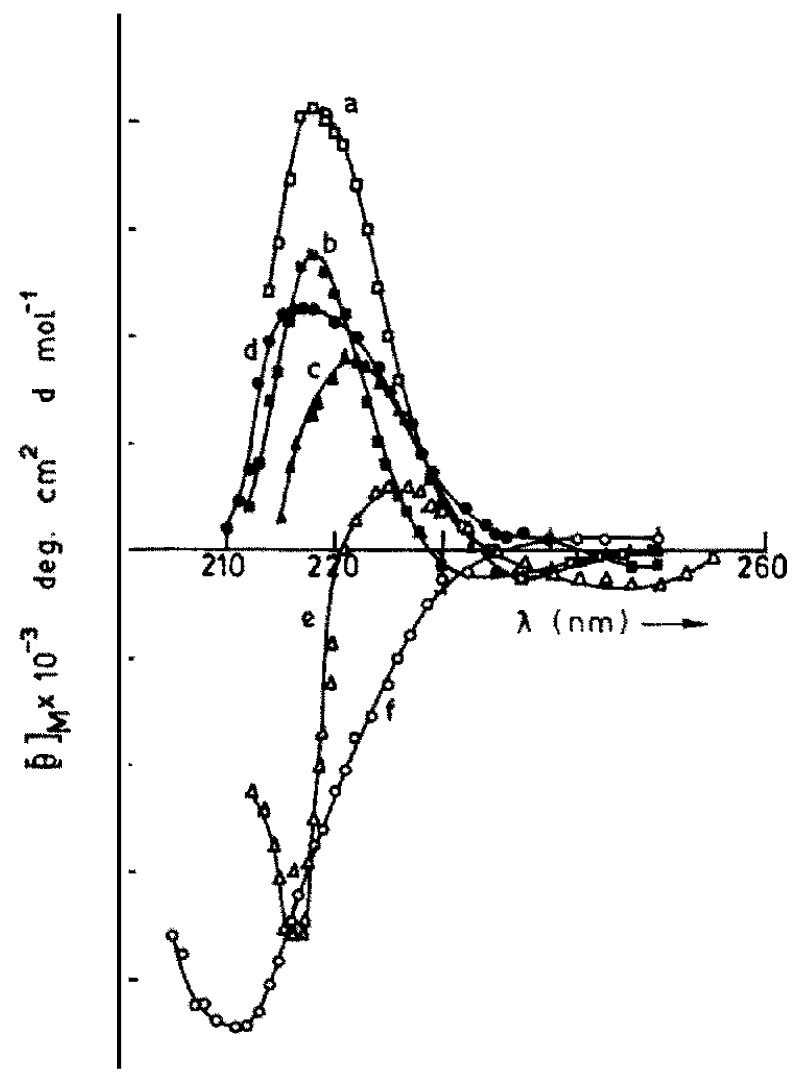

Fig.3.CD spectra ofprotected tetrapeytide amides. BoAib-Gly-Phe-Met-NH, 2 in (a) MeOH and (b) TFF; Boc$\mathrm{Aib}-\mathrm{Aib}$-Phe-Met-NH, 3 in (c) MeOH and (d) TFE; BocGly - Aib - Phe $-\mathrm{Met}^{-\mathrm{NH}_{2}} 4$ in (e) $\mathrm{MeOH}$ and (f) TFE.

$\mathrm{NH}$ has a low $\mathrm{d} \delta / \mathrm{d} T$ value $\left(2.77 \times 10^{-3} \mathrm{ppm} /{ }^{\circ} \mathrm{C}\right)$ characteristic of a solvent shielded or intramolecularly hydrogen-bonded $\mathbf{N H}$ group, whereas the $\mathrm{d} \delta / \mathrm{d} T$ value for the Met NH is indicative of a solventexposed proton [26]. The $\mathrm{d} \delta / \mathrm{d} 7 \mathrm{v}$ values in table 1 also suggest that in $\mathbf{3}$ and $\mathbf{4}$ both Phe and Met MI groups are intramolecularly hydrogen bonded. These results, together with the known stereochemical preferences of Aib residues [21-25] lead us to conclude that in 2, $\beta$-turn structures having Aib-Gly as the corner residues are significantly populated. This conformation is stabilized by a $4 \rightarrow 1$ hydrogen bond between the Boc CO- and Phe NH-groups (fig.4a). In peptides 3 and 4 the NMR data favours incipient $3_{10}$ helical structures formed by consecutive type III $\beta$-tums having X-Aib and Aib-Phe as the corner residues ( $X=\mathbf{A i b}$ in $\mathbf{3}$ and Gly in 4). These conformations require that both Phe and Met NH groups are intramolecularly hydrogenbonded (fig.4b). Such structures have been unambig

Table 1

CD parameters and NMR temperature coefficients (NH protons) in sukephalin fragments

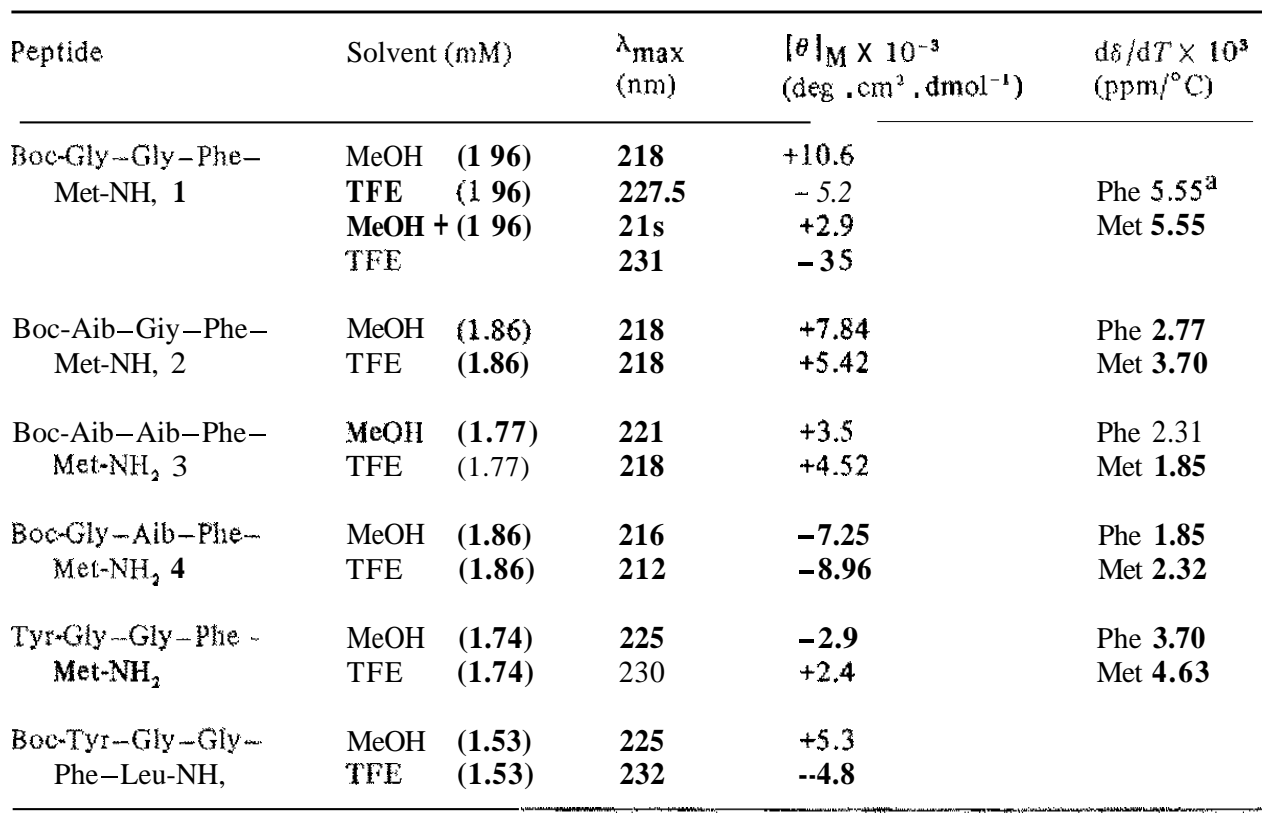

a Temperature coefficients determined for Boc-Gly - Gly - Phe-Met 0 Me 


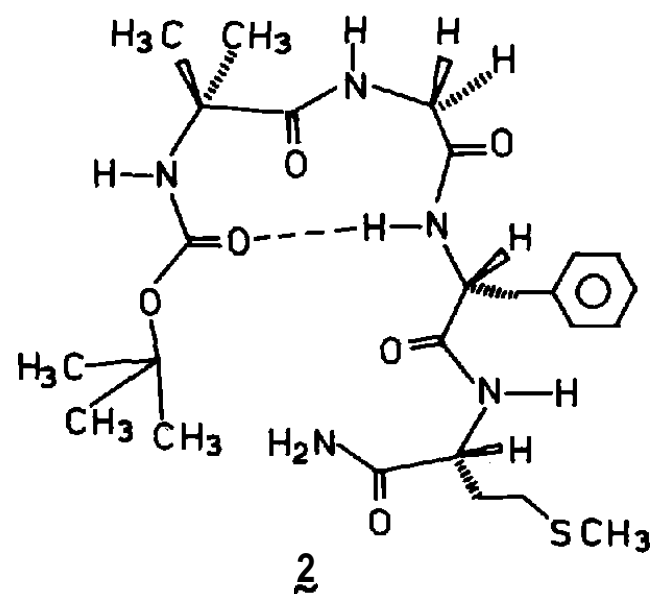

(a)

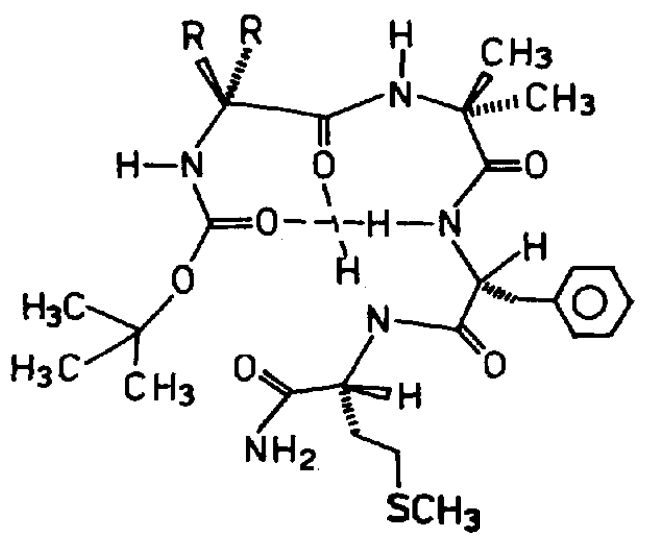

$\mathrm{R}=\mathrm{CH} 3 \quad 3$

(b)
$\mathrm{R}=\mathrm{H} \stackrel{4}{\sim}$

Fig.4. Proposed conformations for (a) Roc-Aib-Gly-Phe-Met-NH, 2 and (b) Boc-Aib-Aib-Phe-Met-NH, 3 or Boc-Gly-AibPhe-Met-NH, 4.

uously established in solution and solid state for Aib containing oligopeptides $[21-25]$.

The CD data presented above show that peptides with the Gly-Gly sequence exhibit similarities to the Aib analogs 2 or 4, depending on the solvent conditions. It thus appears that both Gly ${ }^{2}-\mathrm{Gly}^{3}$ and $\mathrm{Gly}^{3}-$ Phe $\beta$-turn conformations for enkephalins may be energetically close, leading to large solvent-dependent changes in conformer populations. This may account for the apparently conflicting proposals put forward in the literature. Theoretical studies have favoured $\mathrm{Gly}^{2}-\mathrm{Gly}^{3}$ p-turn structures $[14,27]$ and a type I' $\mathrm{Gly}^{2}-\mathrm{Gly}^{3} \beta$-turn has been observed in the solid state [28]. Spectroscopic studies in solution have, however, been interpreted in terms of Gly ${ }^{3}$-Phe $e^{4} 0$-turns [10] or random conformations [11]. The reversal in signs of the CD bands in Tyr-Gly-Gly-Phe-Met- $\mathrm{NH}_{2}$ as compared to 1 may reflect the influence of the Tyr residue on the energetics of the different $\beta$-turn structures. The studies on the model tetrapeptides reported here eliminate contributions due to the aromatic ring of Tyr, a feature considered in earlier studies of enkephalins [18]. Detailed interpretations of enke. phalin CD spectra must also consider the changes in the signs of the bands for the various categories of 0 -turns, predicted from theoretical calculations [29]. The possibility that different well-defined, folded conformational states are populated in peptides with sequences related to enkephalins, is relevant in view of recent reports of multiple receptor sites for opioid ligands $[\mathbf{1 5 , 1 7 1}$. Biological responses induced by opioid peptides could, in principle, be modulated by altering populations of folded conformations.

\section{Acknowledgements}

This research was supported by a grant from the Department of Science and Technology and the University Grants Commission. T. S. S. is $\boldsymbol{a}$ recipient of a fellowship from the Indian Council of Medical Research. P. B. is a recipient of a UGC Career Award.

References

[1] Coy, D. H. and Kastin, A. J (1980) Pharmacol. Therap. $10,657-668$.

[2] Marley, J. S. (1980) Annu, Rev. Pharmcol. Toxicol. 20, $81-110$.

[3] Miller, R. J., Chang, K. J., Cuatrecasas, P., Wilkinson, S., Lowe, L., Beddell, G. and Follenfant, R. (1978) in: Centrally Acting Peptides (Hughes, J. ed) pp. 195-213, MacMillan, London.

[4] Jones, C. R., Gibbons, w. A. and Garsky, V. (1976) Nature 262,779-782.

[5] Roques, B. P., Garbay-Jaureguiberry, C., Oberlin, R., Anteunis, M. and Lala, A. K. (1976) Nature 262, $778-779$. 
[6] Garbay-Jaureguiberry, C., Roques, A. P., Oberlin, R., Anteunis, M. and Lala, A.K. (1976) Uiochem. Riophys. Res. Commun. 71,558 565.

[7] Khaled, M. A., Long, M. M. , Thompson, W. D., Bradley, K. J., Brown, G.B. and Urry, D, W. (1977) Biochem. Biophys. Res. Commun. 76, 224-231.

[8] Anteunis, M., Lala, A. K., Garbay-Jaureguiberry, C. and Roques, B. P. (1977) Biochemistry 16. 1462-1466.

[9] Jones, C., Garsky, V. and Gibbons, W. A. (1977) Biochem. Biophys. Res. Cornrnun. 76,619--625.

[10] Stimson, E. R., Meinwald, Y.C. and Scheraga, H. A. (1979) Biochemistry 18,1661-1671.

[11) Fischman, A.J., Riemon, M. W. and Cowbum, D. (1978) FEBS Let:. $94,236-240$.

[12] Schillor, F. W., Yam. C. IF and Lis . M. (1977) Biochemistry $16,1831-1838$.

[13] Gorin, F. A., Balasubramanian, T. M. ,Barry, C. [J, and Marshall, G. R. (1978) J. Supramol. Struct. 9, 27-39.

[14] Bradbury, A. F.. Smyth, D. G. and Snell, C. K. (1976) Nature 260,165-166.

[15] Smith, J. R. and Simon, E. J. (1980) Proc. Natl. Acad. Sci, USA 77, 281-284.

[161 Chang, K. J. and Cuatrecasas, P. (1979) J. Biol. Chcm. 254,2610-2618.

[17] Lord, J. A. H., Waterfield, A. A., Hughes, J. and Kosterlitz, H. W. (1977) Nature 267, 495-499.

[18] Soos, J., Berzetei, L, Bajusz, S. and Ronai, A. Z. (1980) Life Sci. 27, 129-133.
[19] Nagaraj. R. and Balaram, P. (1978) FEBS Lett. 96, 273-276.

[20] Nagaraj, R., Sudha, T. S., Shivaji, S. and Balaram, P. (1979) FEBS Lett. 106,271- 274.

[21] Nagaraj, R. and Balaram, P. (1981) Acc. Chcm. Kes. in press.

[22] Nagaraj, R., Shamala, N. and Balaram, P. (1979) J. Am. Chem. Soc. 101, 16-20.

[23] Rao, Ch. P., Nagaraj, R.. Rao, C. N. R. and Balaram, P. (1980) Biochemistry 19,425-431.

124) Nagaraj, R. and Balaram, P. (1981) Biochemistry 20, $2828-2835$

[25] Smith, G. D., Pleinev, V.Z., Duax, W. L. Balasubramanian, T.M., Bosshard, H. E., Czerwinski, E. W., Kendrick, N. E., Mathews, F. S. and Marshall, G. R. (1981) J. Am. Chem. Soc. $103.1493-1501$.

[26] Hubry, V.J. (1974) in: Chemistry and Biochemistry of Amino Acids, Peptides and Proteins (Weinstein, B. ed) vol. 3, pp. 1-188. Dekker, New York.

[27] Isogai, Y., Nemeiny, G. and Scherags, H. A. (1977) Proc. Natl. Acad. Sci. USA 74, 414-418.

[28) Smith, G. D. and Griffin, J, F. (1978) Science 199, $1214-1216$

[29] Woody, R. W. (1974) in: Peptides, Polypeptides and Proteins (Blout, E. R. et ai. eds) pp. 338-350, Wiley, New York. 